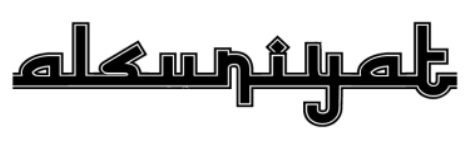

JURNAL PENELITIAN BAHASA, SASTRA, DAN

BUDAYA ARAB

P-ISSN: 2615-7241 | E-ISSN: 2721-480X // Vol. 3 No. 2 | 139-153

๑ https://ejournal.upi.edu/index.php/alsuniyat/index

\title{
The Use of Semantic Translation Method in Dau'u al-Misbāh fĩ Bayāni Ahkāmi al-Nikāh
}

\author{
Nauval Fitriah, Moch. Syarif Hidayatullah \\ Universitas Islam Negeri Syarif Hidayatullah Jakarta, Indonesia \\ Email: nfitryah@gmail.com
}

\begin{abstract}
:
This study was aimed at investigating the use of semantic translation method in the translation of the Dau'u alMisbāh fi Bayāni Ahkāmi al-Nikāh by K.H. Hasyim Asy'ari. A descriptive qualitative method was used in this study. After translating the data objects, the analysis process was carried out by describing the use of semantic translation method applied to translate the text. The results of this study revealed that semantic translation method used in translating Dau'u al-Misbāh fi Bayāni Ahkāmi al-Nikāh was an effective method to use in translating such classical texts, in which it eases the translator to produce translations that are acceptable in the target language (TL), easy to understand, and as closely as possible with the meaning of the sourch language (SL), and help the translator to preserve the writer's ideas.
\end{abstract}

Keywords:

Heritage book; Semantic translation; Method

\section{INTRODUCTION}

A translation method is the orientation that the translator wants to achieve in his translation. In other words, the translation method is a particular way chosen and believed by the translators in translating such texts (Molina \& Albir, 2002, p.507). Thus, methods are global options that affect the translation text as a whole. The translation method affects the way of translating the micro-units of a text. The method chosen is also a strategy guidance and translation technique so that there is a synergy between them to produce a functional and adequate translation for the target audience. Furthermore, semantic translation is more flexible and considers the aesthetic elements of the SL text by compromising the meaning as long as it is reasonable. Semantic translation is also more flexible than faithful translation which is more obliged by SL.

Furthermore, the semantic translation method is a suitable method for translating classical texts. Both authoritative and expressive texts are texts that their content and style, ideas and words, and structure are equally important. The source text used as the object in this study is an authoritative text, in which the text is the writer's thoughts that its substance is a topic coming from a religious text in the context of fiqh. Even though the semantic translation method is oriented 
ALSUNIYAT: Jurnal Penelitian Bahasa, Sastra, dan Budaya Arab

towards the TL and stays within the scope of the TL culture, the translator could make a little concession in the TL by simply changing the meaning that is not so important and does not denounce the ST's (source text) message itself (Suryawinata \& Hariyanto, 2003).

Newmark (1988) points out that, regarding semantic translation, "semantic translation takes more account of the aesthetic value". Later, he adds that "semantic translation is more flexible, admits the creative exception to $100 \%$ fidelity and allows for the translator's intuitive empathy with the original; semantic translations is used for expressive texts; semantic translation is personal and individual, follows the thought processes of the writer, tends to over-translate, pursues nuances of meaning, yet aims at concision in order to reproduce pragmatic impact."

Semantic translation method is a translation method oriented towards the SL. The translation process is carried out through knowledge of the basic patterns of the SL including word units, phrases/collocations, clauses and contexts to get meanings that are appropriate to the culture of the SL. In general, the semantic translation method considers the language maturity level of the ST (source text) writer and follows the writer's thought process which is personal and individual. It is because semantic translation tries to divert as closely as possible the contextual meaning of the TL which is exactly the same as the semantic and syntactic structure of the SL, and the meaning of words and sentence in terms of the context of the SL (Sayogie, 2008). Later, it is emphasized by Al Farisi (2011) stating that, the results of semantic translation are more flexible and allow the translator's intuition to empathize with the TL.

Along with the translation and the islamization process in Indonesia, the religious texts which are part of the classical texts play an important role. In terms of classical texts, Hidayatullah (2014) states that, regarding classical Arabic texts, there are differences aspects from those stated by Hoed. There are other aspects that have to be considered in terms of the format and style of the text. In Arabic texts, changes in the terms of format and style of the text are vividly showed in 100year-old text or over. Classical texts, in Arabic texts, are texts that are estimated to be more than 100 years old and texts written less than 100 years old yet using the format and style of the classical text.

Translation activities are required in order to transmit and inform the wider community and the next generation about the classical texts. Translation is also important to preserve the ancient cultures that contains noble values in classical texts. Most of the classical texts in the form 
ALSUNIYAT: Jurnal Penelitian Bahasa, Sastra, dan Budaya Arab

of religious texts in Indonesia are the masterpieces of scholars, both Middle Eastern scholars, Jawi (Southeast Asian) scholars and their students. In Indonesia, classical texts are believed to be a legacy of intellectual property from the antecedent scholars and scientists, as proven by many works of Indonesian scholars recognized internationally.

K.H. Hasyim Asy'ari is one of the great Indonesian scholars who has distinctive thoughts and is very influential today. Kiai Hasyim is an Indonesian scholar who is productive in expressing his thoughts in writing and it is showed by his numerous works, often used as a reference for the society problems in the present time. The book Dau'u al-Misbāh fỉ Bayāni Ahkāmi al-Nikāh is one of his works which only discusses about marriage. It is composed in a concise, systematic, and easily understood language, especially for commoners. In defining marriage, Kiai Hasyim chooses to quote the opinion of one of the imam (preacher) who prioritizes worship over marriage.

It is different with the other Syafi'iyah scholars such as Ibn Hajar al-Asqalani in his book Bulūgu al-Maram who cites the hadith that marriage is included in the Prophet's sunnah (alAsqalani, 1994, p. 288). In Fathul Mu'īn by Shaykh Zainuddin al-Malibary, it is said that no worship is recommended since the time of Prophet Adam until it continues to heaven except having faith and marriage (al-Malibary, n.d, p.253). However, in Ḍau'u al-Misbāh fï Bayāni Ahkāmi al-Nikāh, it is said that marriage is part of the desire of lust, not part of the way to get closer to Allah (Asy'ari, n.d, p.4). From many phenomenal and translated works of Kiai Hasyim, the book Dau'u al-Misbāh fì Bayāni Ahkāmi al-Nikāh is one of his works that has not been found its translation in Indonesian.

Regarding the translation of books today, both the Holy Quran and Islamic books such as the heritage book include faith, tașawwuf, fiqh and linguistic books such as jurūmiyyah and balāgah, have been translated from Arabic to Indonesian.

Regarding the translation of holy books, there have been several studies conducted such as a study conducted by Syihabudin (2018). In his research he examined transculturation in translating pronouns in the Sundanese translation of the Holy Qur'an. His research showed that the translation was able to equivalent the concept of number ('adad) in the recipient language through the affixation process, but has not been able to fulfill the gender aspect. The translation also considers the interpersonal meanings and the relationship between speech partners by involving cultural elements of politeness into the translation. This is a form of transculturation from neutral, 
ALSUNIYAT: Jurnal Penelitian Bahasa, Sastra, dan Budaya Arab

egalitarian, and exclusive to being impartial, inclusive, polite, and communicative as the result of the use of the communicative translation method.

Another study regarding the translation of holy books was conducted by Al Farisi (2017). His study was aimed at revealing the accuracy of the translation of cultural nuances of imperative verses. The sample of his study was purposively selected in the form of imperative verses having certain pragmatic meanings. The accuracy of the imperative verses translation could not be separated from the translation techniques and procedures that were applied in overcoming the micro units of the translation. The study corpus applied used the Qur'an translated by the Ministry of Religion.

Further, Maulana (2019) conducted a study on the analysis of command sentences (amr) in surah Yāsinn in the translation of the Al-Qur'an noble reading of HBJ. The results of his study showed that there were 12 forms of amr meaning haqiqi, in seven verses that are in verses $11,26,45,61$, 64, 79, and 82. Meanwhile, there were five verses that had the form of amr which means balägi meaning li-irsyād (suggestion); verses 13, 20, 21, 25, and 47. Furthermore, the translation technique used by HBJ in surah Yāsinn, the literal technique was used $80 \%$ and $20 \%$ was the use modulation technique.

Another study on the translation of Islamic books was also carried out by Ainurrafiq (2015). His study focused on the analysis of errors in the translation of al-balāgah al-wādihah by Ali alJarim and Mustafa Amin. The result of this study showed that there was an error in the sentence structure of the TL, including the sequence of sentence positions. The errors in use of the effectiveness of the sentences were closely related to the unnecessary translation of texts and repetition of the mentioned words. Errors in translating vocabulary included choosing incorrect equivalents, not the synonym of the words, and inaccurate translation of idioms. In addition, errors were also found in the aspect of elimination.

Further study on Islamic books was also carried out by Masrukhi (2017) entitled Penerjemahan Arab-Jawa Tradisi Pesantren pada Karya Kitab-Kitab Klasik: Analisis Fungsi (the Arabic-Javanese translation of the Islamic boarding school tradition in classical books: analysis of functions). The results of this study showed that the function markers of the grammatical unit in the Arabic classical books (al-kutub al-mu'tabarah) were divided into four parts. The division was carried out to show the uniqueness of the Arabic language structure. The division included: a)

Vol. 3 No. 2 | 139-153

ALSUNIYAT, p-ISSN: 2615-7241, e-ISSN: 2721-480X 
ALSUNIYAT: Jurnal Penelitian Bahasa, Sastra, dan Budaya Arab

function markers of mubtada' and khabar; b) function markers of fā'il and nāib fā'il; c) syntactic function markers of maf'ūl bih; and d) explanatory function markers including maf'ūl fìh, maf'ūl muțlaq, maf'ūl li ajlihi, hāl, and tamyīz. Thus, this is a tradition of Islamic interpretation in boarding school to get the knowledge of Arabic classical books learned and knowledge about Arabic grammar.

Regarding the translation of the heritage book specifically called the taisīr al-khalaq book, the study carried out by Rohmah and Muklas (2018) showed that in the use of bandongan method, the teacher applied the word for word and literal methods to translate the heritage book text. Then, in the use of sorogan method, the students applied the word for word and literal method when reading the heritage book. From the explanation of those various studies mentioned before, it could be said that, regarding the Islamic books, there is still a gap that has not been given any attention, namely the use of semantic translation method in Dau'u al-Misbāh fĩ Bayāni Ahkāmi alNikāh by K.H. Hasyim Asy'ari. The researcher would examine the use of semantic translation method.

\section{METHOD}

This study used a qualitative-descriptive method. This study focused on analyzing the translation results of Dau'u al-Misbāh fì Bayāni Ahkāmi al-Nikāhi. The data were gained from Dau'u al-Misbāh fỉ Bayāni Ahkāmi al-Nikāhi then they were analyzed by describing comprehensively the use of semantic translation method applied in translating Dau'u al-Misbāh fí Bayāni Ahkāmi alNikāhi from Arabic to Indonesian.

Further, the researcher described the procedure of the analysis process so that this study was carried out systematically and gradually. The procedure of the research involved: a) translating Ḍau'u al-Misbāh fỉ Bayāni Ahkāmi al-Nikāh using several dictionaries as references; and b) describing the translation process using semantic translation method.

The researchers used library research design to obtain the required data to produce accurate results. Then, in order to maximize the research results, the researcher used secondary data sources that refer to e-journals on the internet and encyclopedias. 
ALSUNIYAT: Jurnal Penelitian Bahasa, Sastra, dan Budaya Arab

\section{RESULTS AND DISCUSSION}

Semantic translation method is a translation method oriented towards the TL. The translation process is carried out through knowledge of the basic patterns of the SL including word units, phrases/collocations, and clauses and contexts to get the appropriate meanings with the culture of the SL.

In this study, the researcher only took a few texts as samples from the accountability of the translation results, as well as how the semantic translation method was applied. Because there are so many sentences in the TL, it might be impossible to describe everything. Thus, the following is an analysis of the use of the semantic translation method applied in the translation of Dau'u alMisbāh fì Bayāni Ahkāmi al-Nikāh.

\section{Text I}

\begin{tabular}{l|c}
\hline \multicolumn{1}{c|}{ The text of the TL } & The text of the SL \\
\hline $\begin{array}{l}\text { Hukum-hukum Pernikahan (Laws of } \\
\text { Marriage) }\end{array}$ & \\
\hline
\end{tabular}

The translation method used in above sample is translation method oriented to the TL emphasizing on the straightforwardness of the title. In the sentence باب الأول في بيان أحكام النكاح that is the title of the chapter, the translator only defined "hukum-hukum pernikahan (the laws of marriage)" to make it feel more straightforward and sufficient in order to represent the whole chapter explaining about the definitions to the mandatory, sunnah, makrūh and harām laws of marriage. The translator did not follow the writing systematics of the writer who used the word "Bāb (chapter)".

\section{Text II}

\begin{tabular}{|c|c|}
\hline The text of the TL & The text of the SL \\
\hline $\begin{array}{l}\text { Terdapat beberapa persoalan mengenai } \\
\text { pernikahan. 1. Pendapat Imam Haramain, } \\
\text { "Menikah merupakan sebagian dari hawa } \\
\text { nafsu belaka, bukan sebagian dari cara } \\
\text { mendekatkan diri pada Allah." (There are } \\
\text { several problems regarding marriage. } 1 .\end{array}$ & والقروبات مسائل ، الأولى نص الإمام أن النكاح من الثهوات لا من \\
\hline
\end{tabular}


ALSUNIYAT: Jurnal Penelitian Bahasa, Sastra, dan Budaya Arab

Imam Haramain's opinion, "Getting married is a part of lust, not a part of how to get closer to Allah)

In the context of fiqh shäfi'i, the word الامام is the word addressed to Imam Haramain. His full name is Imam al-Haramain Dhia'u al-Din Abdu al-Malik Ibn Yusuf al-Juwaini al-Syafi'i. Therefore, in the word الامام the translator chose the meaning of "Imam Haramain".

The translation method used is a method oriented to the SL by bringing out the meaning of the context and context contained in the sentence. In the context of fiqh mażhab Shäfi'iyyah, the word is the word addressed to Imam Haramain. His full name is Abdul Malik bin Yusuf AlJuwaini Assyafi'i (Qudsi, M. A., Hamid, A. n.d.). Therefore, in the word الإمام the thanslator chose the meaning "Imam Haramain." The word القروبات which is the plural form of the word قربة according to the Al-Munawwir dictionary means "dekat (close)." (Munawwir, 1997, p.1102). The translator defines it "cara mendekatkan diri pada Allah (how to get closer to Allah)" because if it is only interpreted literally it does not convey the message the SL. The word is also in a context which is an antonym of the word الثهوات; the plural form of the word شهوة, according to the Al-Munawwir dictionary, meaning lust; taste. The word lust is also an absorption word in Indonesian. According to the $K B B I$ (the Big Indonesian Dictionary) application dictionary, it means lust or desire to have intercourse; infatuation. Therefore the translator chose the meaning of "hawa nafsu (lust)."

\section{Text III}

\begin{tabular}{|c|c|}
\hline The text of the TL & The text of the SL \\
\hline $\begin{array}{l}\text { Menikah disunahkan bagi seseorang yang } \\
\text { sangat ingin memenuhi kebutuhan } \\
\text { biologisnya dan mampu untuk memberikan } \\
\text { mahar serta mampu untuk menafkahi. Jika } \\
\text { sebaliknya, disunahkan bagi seseorang } \\
\text { tersebut untuk tidak menikah. (Marriage is } \\
\text { legalized for someone who is eager to fulfill } \\
\text { his biological needs and is able to provide a } \\
\text { dowry and is able to provide for a living. If it }\end{array}$ & و والنقة يستحب ، وممن لم تنتق نفسه اليه فالمسته الى الوطع وقدر على المهر ان لا يتزوج \\
\hline
\end{tabular}

Vol. 3 No. 2 | $139-153$

ALSUNIYAT, p-ISSN: 2615-7241, e-ISSN: 2721-480X 
ALSUNIYAT: Jurnal Penelitian Bahasa, Sastra, dan Budaya Arab

is otherwise, it is legalized for that person to not get marry).

The translation method used in above sample is a method oriented to the TL readability with a communicative principle that chooses a more general diction and clarifies certain parts of the text. The word تاقت according to the Alma'any application dictionary means rindu (longing); ingin yang sangat (eager) (Sharia, A. 2016). Meanwhile, according to the Al-Munawwir dictionary it means longing; really wanting something or someone, the translator chose the diction "sangat ingin (eager)" and the word الوطء meaning to step on; enter; climbed up; hook up; have sex, is chosen and translated to "memenuhi kebutuhan biologis (meet biological needs)". The sentence كمن ناقت نفسه الى الوطء is translated to "Bagi seseorang yang sangat ingin memenuhi kebutuhan biologisnya (for someone who is eager wants to fulfill his biological needs)", although it becomes longer than the TL when translated. However, the translation has become more polite and clear in the terms of its message. Then, the sentence is only translated as "jika sebaliknya (if it is otherwise) ", the translator translated the sentence by only bringing up the contextual meaning, and the message was conveyed.

\section{Text IV}

\begin{tabular}{|c|c|}
\hline The text of the TL & The text of the SL \\
\hline $\begin{array}{l}\text { Disunahkan menikah dengan perempuan } \\
\text { perawan, kecuali terdapat alasan lain seperti } \\
\text { bagi seorang penderita impoten (It is legal to } \\
\text { marry a virgin woman, unless there are } \\
\text { other reasons such as for a person with } \\
\text { impotence) }\end{array}$ & الر ابعة يستحب ان يكون الزوجة بكر الا لعذر كضعف آلته \\
\hline
\end{tabular}

The translation method used in above sample is a method is oriented to the TL readability with communicative principles that are easy to read, obliged to the context, and the time of translation. The word الزوجة according to the Al-Munawwir dictionary means wife, but the translator chose the meaning of "perempuan (woman)" because the next word is I which means girl; virgin. The word wife according to the Indonesian dictionary means a married woman or a 
ALSUNIYAT: Jurnal Penelitian Bahasa, Sastra, dan Budaya Arab

woman whose a husband; woman who is married, while the message in the TL is that a woman, كضعف آلته عن الافتضاض اى از الة البكارة not a wife meaning a woman who has been married. The sentence which if interpreted literally or faithfully to the TL means "seperti lemahnya penis untuk menghilangkan keperawanan (like a weak penis to ravish virginity)". However, it was only translated "seperti bagi seorang penderita impoten (as for a person with impotence)" in which the results are more effective and easier to understand.

\section{Text V}

\begin{tabular}{|c|c|}
\hline The text of the TL & The text of the SL \\
\hline $\begin{array}{l}\text { "Jangan kamu nikahi } 6 \text { jenis perempuan ini } \\
\text { yaitu, egois, suka mengungkit, mengingat } \\
\text { mantan keluarganya. Jangan kamu nikahi } \\
\text { pula perempuan yang boros, melampau } \\
\text { dalam berhias dan banyak cakapnya. al- } \\
\text { Anānah ialahyang egoismenya tinggi, banyak } \\
\text { mengeluh, selalu mengikat kepalanya. Tidak } \\
\text { ada baiknya menikahi perempuan yang } \\
\text { sengaja buat-buat sakit; al-Manānah ialah } \\
\text { perempuan yang suka memberikan sesuatu } \\
\text { kepada suaminya. Namun, selalu mengungkit } \\
\text { pemberiannya tersebut sampai mengatakan } \\
\text { kepada suaminya "saya telah melakukan ini } \\
\text { dan itu untuk kamu"; al-Hanānah ialah } \\
\text { perempuan yang mengingat mantan } \\
\text { suaminya atau anak dari mantan suaminya. } \\
\text { Perempuan seperti ini harus dihindari untuk } \\
\text { dinikahi; al-Hadāqah ialah perempuan boros } \\
\text { yang banyak ingin dan menuntut suaminya } \\
\text { maktuk membelinya; al-Barāqah, terdapat dua } \\
\text { supaya wajahnya lebih mempesona untuk }\end{array}$ & 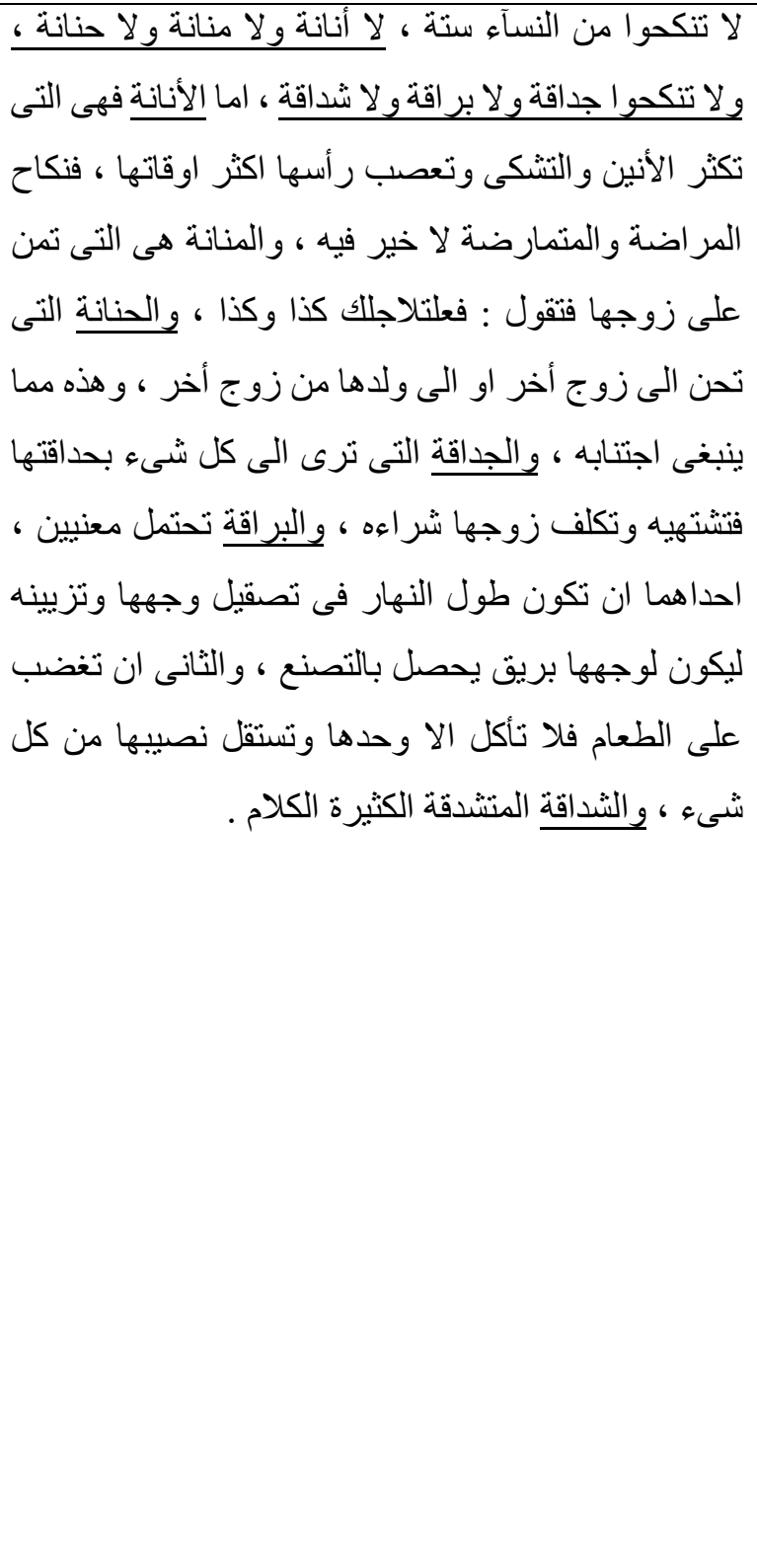 \\
\hline
\end{tabular}


ALSUNIYAT: Jurnal Penelitian Bahasa, Sastra, dan Budaya Arab

mendapatkan pekerjaan. Makna kedua ialah perempuan yang tidak mau makan, dia hanya makan jika sendiri dan menyisihkan makanan untuk dirinya sendiri; al-Syaddāqah ialah perempuan yang banyak cakap (Don't you marry these 6 types of women, namely, selfish, like to pry, considering their former family. Do not marry a woman who is extravagant, the one who overly puts makeup on her face and is too talkative. AlAnānah is the one who has high egoism, complains a lot, and always ties his head. There is no good marrying a woman who deliberately makes sick; al-Manānah is a woman who likes to give something to her husband yet she always brings up her gift until she says to her husband "I have done this and that for you"; al-Hanānah is a woman who remembers her ex-husband or children of her ex-husband. Women like this should be avoided in marriage; al-Hadāqah is a wasteful woman who wants and demands her husband to buy; al-Barāqah, there are two meanings. First, she likes to put on makeup all the time so that her face is more charming to get a job. The second meaning is a woman who does not want to eat, she only eats if she is alone and takes food away for herself; al-Syaddāqah is a very talkative woman) 
The translation method used is a method oriented to the readability of the TL with a more general and effective communicative principle, although it can be longer than the TL when it is translated. The word أنانة منانة حنانة جداقة بر اقة شداقة was translated by choosing the diction assumed to represent the full meaning of each word so that it is translated to "egois, suka mengungkit, mengingat mantan keluarganya. yang boros, melampau dalam berhias dan banyak cakapnya (selfish, like to pry, considering their former family. Do not marry a woman who is extravagant, the الأنانة, الحنانة, الحداقة, البر اقة one who overly puts makeup on her face and is too talkative)”. The words and الشداقة according to the Al-Munawwir dictionary mean those who moan a lot, who mourn, who look sharply, who preen and whose wide mouth is not translated as their meaning. However, it is only transcribed into Indonesian because the sentence after it explains the meaning of each word.

\section{Text VI}

\begin{tabular}{|c|c|}
\hline The text of the TL & The text of the SL \\
\hline $\begin{array}{l}\text { Pertama, kesusahan mencari nafkah halal } \\
\text { untuk kebanyakan orang. Apalagi di zaman } \\
\text { serba susah, kebanyakan perilaku } \\
\text { masyarakatnya keluar dari hukum syariat } \\
\text { dengan beralasan tidak pastinya pendapatan } \\
\text { dan prihatinnya keadaan menjadikan } \\
\text { pernikahan sebagai penyebabnya dan } \\
\text { dimakannya nafkah haram (First, the } \\
\text { difficulty of earning a halāl living for most } \\
\text { people. Especially in times of difficulty, most } \\
\text { of the people's behavior out of Sharia law } \\
\text { due to uncertain income and they blames } \\
\text { marriage for their difficult situation and } \\
\text { haräm livelihood) }\end{array}$ & 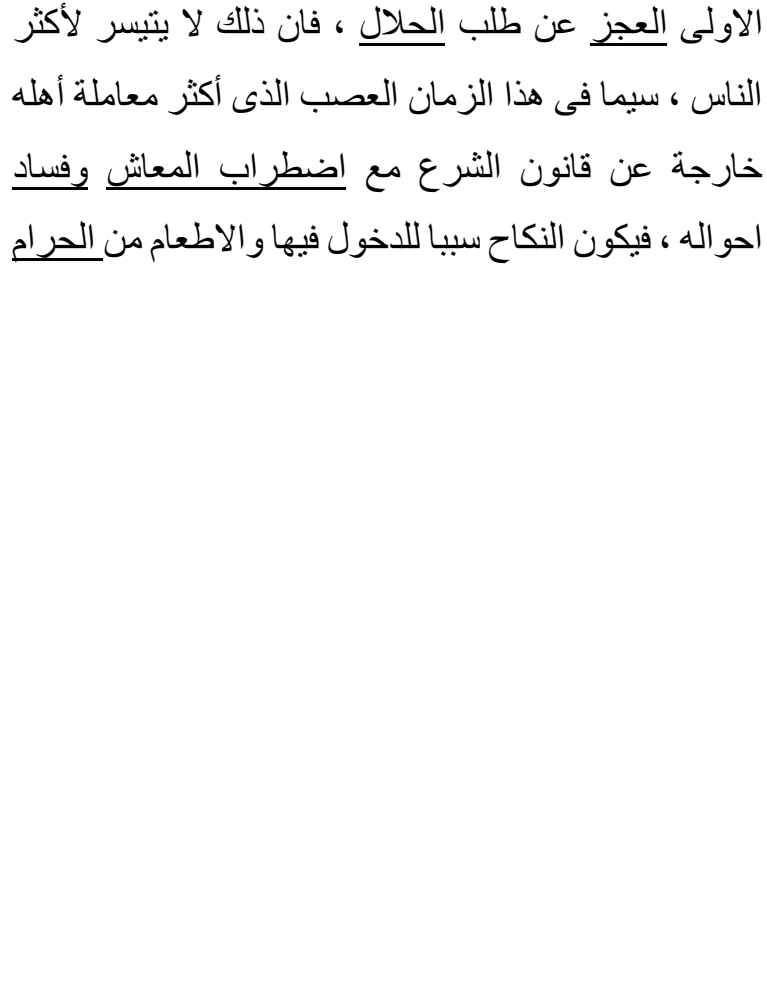 \\
\hline
\end{tabular}

The translation method used in above sample is a method oriented to the readability of the TL with communicative principles emphasizing on the intention of the writer. The word العجز 
ALSUNIYAT: Jurnal Penelitian Bahasa, Sastra, dan Budaya Arab

according to the Al-Munawwir dictionary means incapable; unable; having no power; the weak; the old one is translated as "kesusahan (difficulty)" because the context of the source text refers to the writer's intention which aims to explain the sentence "kesusahan dalam mencari nafkah halal (difficulty in earning a halal living)". The word الحلال which means halal; out of ihram translated by adding the word "nafkah" in the target text (TT), as the explanation of the meaning of the word means wavy; move; shock which becomes a phrase with the word which means payment; wage; livelihood; income translated to "tidak pastinya pendapatan (uncertain income)", which is sufficient to convey the meaning. The word فساد means broken; rotten; remove; canceled translated as "prihatin (concerned)". The word الحرام means to prevent; forbidden; haram translated by adding the word "nafkah", because of emphasizing the message conveyed by the writer of the TL.

\section{Text VII}

\begin{tabular}{|c|c|}
\hline The text of the TL & The text of the SL \\
\hline $\begin{array}{l}\text { Disunahkan meminang dari pihak wali, } \\
\text { kemudian dibacakan khutbah terlebih } \\
\text { dahulu, begitupun sebelum mengucap ijab. } \\
\text { Para sahabat berkata: khutbah disampaikan } \\
\text { dengan memuji kepada Allah, solawat dan } \\
\text { salam bagi Rasulullah, kemudian } \\
\text { menyampaikan wejangan. } \\
\text { menyampaikan (Asked to propose from the } \\
\text { guardian, then the sermon is read first, as } \\
\text { well as before giving consent. The } \\
\text { companions said: the sermon was delivered } \\
\text { with praise to Allah, may peace and } \\
\text { blessings of Allah be upon Prophet } \\
\text { Muhammad, then conveyed exhortations. } \\
\text { Khatib said): }\end{array}$ & 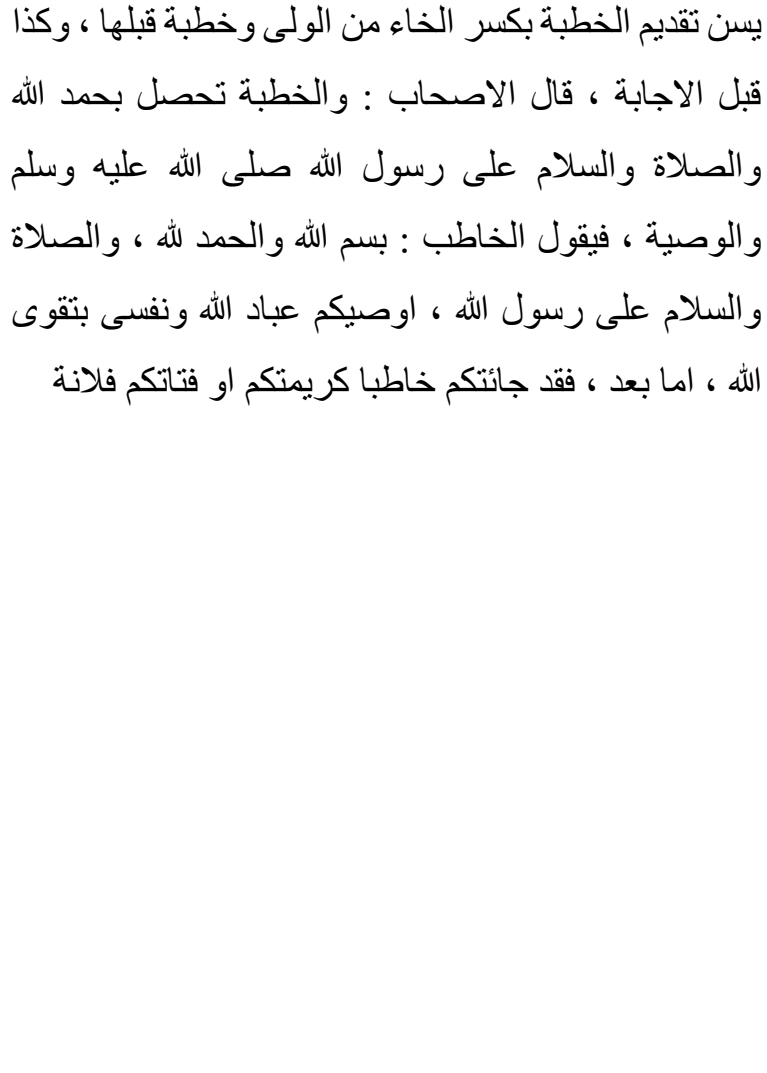 \\
\hline
\end{tabular}


ALSUNIYAT: Jurnal Penelitian Bahasa, Sastra, dan Budaya Arab

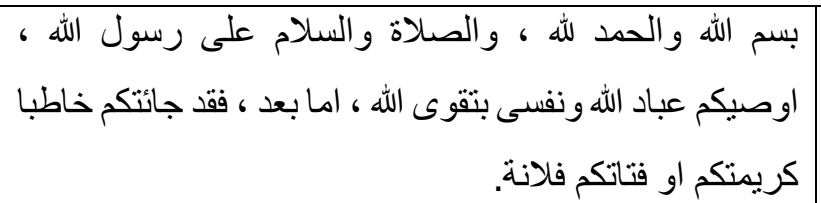
Dengan menyebut nama Allah dan segala puji milik Allah. Solawat dan salam bagi Rasulullah saw. Aku mewasiatkan kepada kalian hamba Allah dan diriku dengan takwa kepada Allah. Telah datang kepada kalian seorang khatib untuk meminang putri kalian fulānah (By chanting the name of Allah and all praise belongs to Allah. May peace and blessings of Allah be upon Prophet Muhammad, the Messenger of Allah. I inherit to you servants of Allah and myself with piety to Allah. It has come to you a preacher to propose to your daughter fulānah.

The translation method used in above example is a method oriented to the readability of the TL with a communicative principle emphasizing on the readers of the TL in order to understand the thoughts and content of the cultural aspects of the SL. In the translation above, there is a repetition of the same sentence which is as same as the TL.

بسم الله و الحمد لله ، و الصلاة و السلام على رسول الله ، اوصيكم عباد الله ونفسى بتقوى الله ، اما بعد ، فقد جائتكم خاطبا كريمتكم او فتاتكم فلانة

Then, it is translated so that the meaning is understood.

"Dengan menyebut nama Allah dan segala puji milik Allah. Solawat dan salam bagi Rasulullah Saw. Aku mewasiatkan kepada kalian hamba Allah dan diriku dengan takwa kepada Allah. Telah datang kepada kalian seorang khatib untuk meminang putri kalian fulānah (By chanting the name of Allah and all praise belongs to Allah. May peace and blessings of Allah be upon Prophet Muhammad, the Messenger of Allah. I inherit to you servants of Allah and myself with piety to Allah. It has come to you a preacher to propose to your daughter fulānah) ". 
ALSUNIYAT: Jurnal Penelitian Bahasa, Sastra, dan Budaya Arab

Because the sentence is a sentence that has a meaning as a suggestion to use the sentence in the same context that the writer exemplifies in the TL.

\section{CONCLUSIONS}

In translating Dau'u al-Misbāh fi Bayāni Ahkāmi al-Nikāh by K.H. Hasyim Asy'ari, the researcher used semantic translation method. After translating the book, the researcher could conclude that the use of semantic translation method in translating Dau'u al-Misbāh fí Bayāni Ahkāmi al-Nikāh helped the translator to produce such a translation that is good, easy to understand, and as close as possible to the meaning of the TL, and helped the translator to maintain the writer's ideas that, as a whole, are concepts related to fiqh. There were several difficulties encountered by the translator when translating the text. They were regarding 1) adjusting the meaning of each word in TL with the basic patterns of language in the TL to get the appropriate meaning according to the TL, 2) understanding the complex meaning of the TL yet in the form of short sentences, and 3) maintaining the writing style of the writer in the TL. It could be concluded that the translation of Dau'u al-Misbāh fĩ Bayāni Ahkāmi al-Nikāh using semantic translation method eased the translator to get an acceptable translation in the TL.

\section{REFERENCES}

Ainurrafiq, F. (2015). Analisa kesalahan dalam penerjemahan kitab al-balāgah al-wāọihah karya Ali al-Jarim dan Mustafa Amin. Jurnal Cendekia, 13(1), 35-48. https://doi.org/10.21154/cendekia.v13i1.236

Al Farisi, M. Z. (2011). Pedoman penerjemahan Arab-Indonesia. Bandung: Remaja Rosdakarya Offset.

Al Farisi, M. Z. (2017). Ketedasan terjemahan ayat-ayat imperatif bernuansa budaya. Jurnal El Harakah, 19(2), 159-176. http://dx.doi.org/10.18860/el.v19i2.3934

Asqalani, I. H. (1994). Bulūgu al-maram. Kuwait: Maktabah Dār al-Salām.

Asy’arî, S. M. H. (n.d.). Dau’u al-misbāh fī bayāni ahkāmi al-nikāh. Jombang: Maktabah al-Turāí alIslāmī.

Hidayatullah, M. S. (2014). Seluk beluk penerjemahan Arab Indonesia kontemporer. Tangerang Selatan: Alkitabah. 
ALSUNIYAT: Jurnal Penelitian Bahasa, Sastra, dan Budaya Arab

Malibary, Z. (n.d.). I'ānah al-thalibin Juz 3. Semarang: Karya Putra.

Masrukhi, M. (2017). Penerjemahan Arab-Jawa tradisi pesantren pada karya kitab-kitab klasik: analisis fungsi. Jurnal SASDAYA, Gadjah Mada Journal of Humanities, 2(1), 283-301. https://doi.org/10.22146/sasdayajournal.31744

Maulana, D. (2019). Analisis kalimat perintah (amr) pada surah Yāsīn dalam terjemahan al-qur'an bacaan mulia hbj. Alsuniyat: Jurnal Penelitian Bahasa, Sastra, dan Budaya Arab, 2(1), 1-14. https://doi.org/10.17509/alsuniyat.v2i1.24348

Molina, L. \& Albir H. (2002). Translation techniques revisited: a dinamic and functionalist approach. Jurnal Meta, 47(4), 498-512. https://doi.org/10.7202/008033ar

Qudsi, M. A., Hamid, A. (n.d.). Syarh lațāifu al-isyārah. Jeddah: Al-Haramain.

Munawwir, A. W. (1997). Al-munawwir kamus Arab-Indonesia. Surabaya: Pustaka Progressif.

Newmark, P. (1988). A textbook of translation. China: Shanghai Foreign Language Education Press.

Rohmah, A., \& Muklas, M. (2018). Aplikasi metode penerjemahan dalam pembelajaran kitab kuning. Titian Ilmu: Jurnal Ilmiah Multi Sciences, 10(2), 92-98. https://doi.org/10.30599/jti.v10i2.324

Sayogie, F. (2008). Penerjemahan bahasa Inggris ke dalam bahasa Indonesia. Jakarta: Lembaga Penelitian Universitas Islam Syarif Hidayatullah.

Sharia, A. (2016). Almaany Arabi-Indonesia. Atef Sharia. Versi 1.2.

Syihabudin, (2018). Transkulturasi dalam penerjemahan pronomina pada terjemahan alquran bahasa sunda, Arabiyat: Jurnal Pendidikan Bahasa Arab dan Kebahasaaraban, 5(1), 1-14. https://doi.org/10.15408/a.v5i1.7794

Suryawinata, Z. \& Hariyanto, S. (2003). Translation bahasan teori \& penuntun praktis menerjemahkan. Yogyakarta: Kanisius.

Vol. 3 No. 2 | 139-153

ALSUNIYAT, p-ISSN: 2615-7241, e-ISSN: 2721-480X 